University of Nebraska - Lincoln

DigitalCommons@University of Nebraska - Lincoln

\title{
Oxidative metabolism in plant/bacteria interactions: characterization of a unique oxygen uptake response of potato suspension cells
}

\author{
C. Jacyn Baker \\ United States Department of Agriculture, jacyn.baker@ars.usda.gov \\ E. W. Orlandi \\ United States Department of Agriculture \\ Kenneth L. Deahl \\ United States Department of Agriculture
}

Follow this and additional works at: https://digitalcommons.unl.edu/usdaarsfacpub

Part of the Agricultural Science Commons

Baker, C. Jacyn; Orlandi, E. W.; and Deahl, Kenneth L., "Oxidative metabolism in plant/bacteria interactions: characterization of a unique oxygen uptake response of potato suspension cells" (2001). Publications from USDA-ARS / UNL Faculty. 336.

https://digitalcommons.unl.edu/usdaarsfacpub/336

This Article is brought to you for free and open access by the U.S. Department of Agriculture: Agricultural Research Service, Lincoln, Nebraska at DigitalCommons@University of Nebraska - Lincoln. It has been accepted for inclusion in Publications from USDA-ARS / UNL Faculty by an authorized administrator of DigitalCommons@University of Nebraska - Lincoln. 


\title{
Oxidative metabolism in plant/bacteria interactions: characterization of a unique oxygen uptake response of potato suspension cells
}

\author{
C. JAGYN BAKER ${ }^{1 *}$, E. W. ORLANDI ${ }^{1}$ and KENNETH L. DEAHL ${ }^{2}$ \\ ${ }^{1}$ Microbiology and Plant Pathology Laboratory, ARS, United States Department of Agriculture, Beltsville, MD 20705, U.S.A. and \\ ${ }^{2}$ Vegetable Development Laboratory, ARS, United States Department of Agriculture, Beltsville, MD 20705, U.S.A.
}

(Accepted for publication June 2001 and published electronically 5 September 2001)

\begin{abstract}
Plant suspension cells have been shown to respond to bacteria or microbial elicitors by producing active oxygen as well as increasing oxygen uptake. Here we characterize a unique two stage oxygen uptake response of potato suspension cells to heat-killed bacteria. Stage 1 occurred within minutes after the addition of heat-killed bacteria; the potato suspension cells responded with a rapid increase in oxygen uptake and reached a steady state approximately $50 \%$ greater than the initial basal rate. Stage 2 began 20-30 min after this new steady state was achieved and was characterized by a slow increase in the oxygen uptake rate over the remaining 90 min period. Calculation of the total oxygen consumption by the plant cells indicated that only a small fraction of the increased oxygen uptake was due to the concomitant production of reactive oxygen species. The protein kinase inhibitor, K-252, inhibited the oxygen uptake response by $80-90 \%$, suggesting the involvement of protein phosphorylation in the oxygen uptake response. The alternate oxidase inhibitor, SHAM, inhibited the elicited oxygen uptake response by about $25 \%$ while a combination of SHAM and KCN almost completely blocked respiration as well as the elicited response. The data indicate that mitochondrial respiration and, in particular, the alternate oxidase, play a significant role in the elicited oxygen uptake response of potato cells.
\end{abstract}

Keywords: reactive oxygen species; hydrogen peroxide; respiratory burst.

\section{INTRODUCTION}

Oxidative metabolism is a broad term referring to an array of metabolic processes that involve the exchange of electrons. The controlled exchange of electrons during normal metabolism allows the energy from their molecular orbits to be harvested for life's processes. Disease of a host can be described as the result of a pathogen's ability to tap into the host's electron flux and divert a portion of the energy for its own use. Oxidative metabolism, via the redox potential, appears to regulate critical physiological processes in living organisms such as gene regulation, cell signaling of both growth and stress responses, and apoptosis $[15,16]$. The cycle of oxidative metabolism can be viewed as originating in plants via photosynthesis

* To whom all correspondence should be addressed. E-mail: bakerc@ba.ars.usda.gov

Abbreviations used in the text: DPI, diphenyleneiodonium chloride; HK-bacteria, heat killed Pseudomonas syringae pv. syringae 61 NalR; K-252, a protein kinase inhibitor; KCN, potassium cyanide; LDC, luminol-dependent chemiluminescence; ROS, reactive oxygen species; SHAM, salicylhydroxamic acid.

Mention of a trade name, proprietary product, or vendor does not constitute a guarantee of the product by the USDA and does not imply its approval to the exclusion of other vendors that may also be suitable. and the activation of electrons from water. In most aerobic organisms the cycle can be viewed as ending with oxygen. With its two unpaired electrons, oxygen is the final recipient of electrons producing water via respiration. Any increase in metabolism due to either stress or growth will directly or indirectly result in an increase in the metabolic electron flux and result in the reduction of oxygen. The latter can be detected as an increase in the rate of oxygen uptake.

Using a multi-electrode oxygen analyser, our laboratory has been able to study the effects of pathogens or pathogen related components on plant metabolic rate by monitoring oxygen uptake in plant suspension cells. The apparatus allows the simultaneous comparison of several treatments over several hours in an open-air environment, preventing oxygen from becoming limiting. Suspension cells have proven to be valuable and necessary tools in dissecting the complex physiology of host/pathogen interactions. Previous studies with this suspension cell model system have demonstrated that recognition of several compatible and incompatible bacterial pathogens is maintained and that early cell death, similar to the hypersensitive response occurs with incompatible pathovars.

Previous studies utilizing these techniques monitored increases in oxygen uptake in tobacco suspension cells 
treated with viable bacteria [6] and heat-killed (HK) Pseudomonas syringae pv. syringae [8]. As in the later study, the use of HK-bacteria as an elicitor avoids the complication of oxygen consumption by viable bacteria, but limits the study to the first phase of oxygen uptake [6].
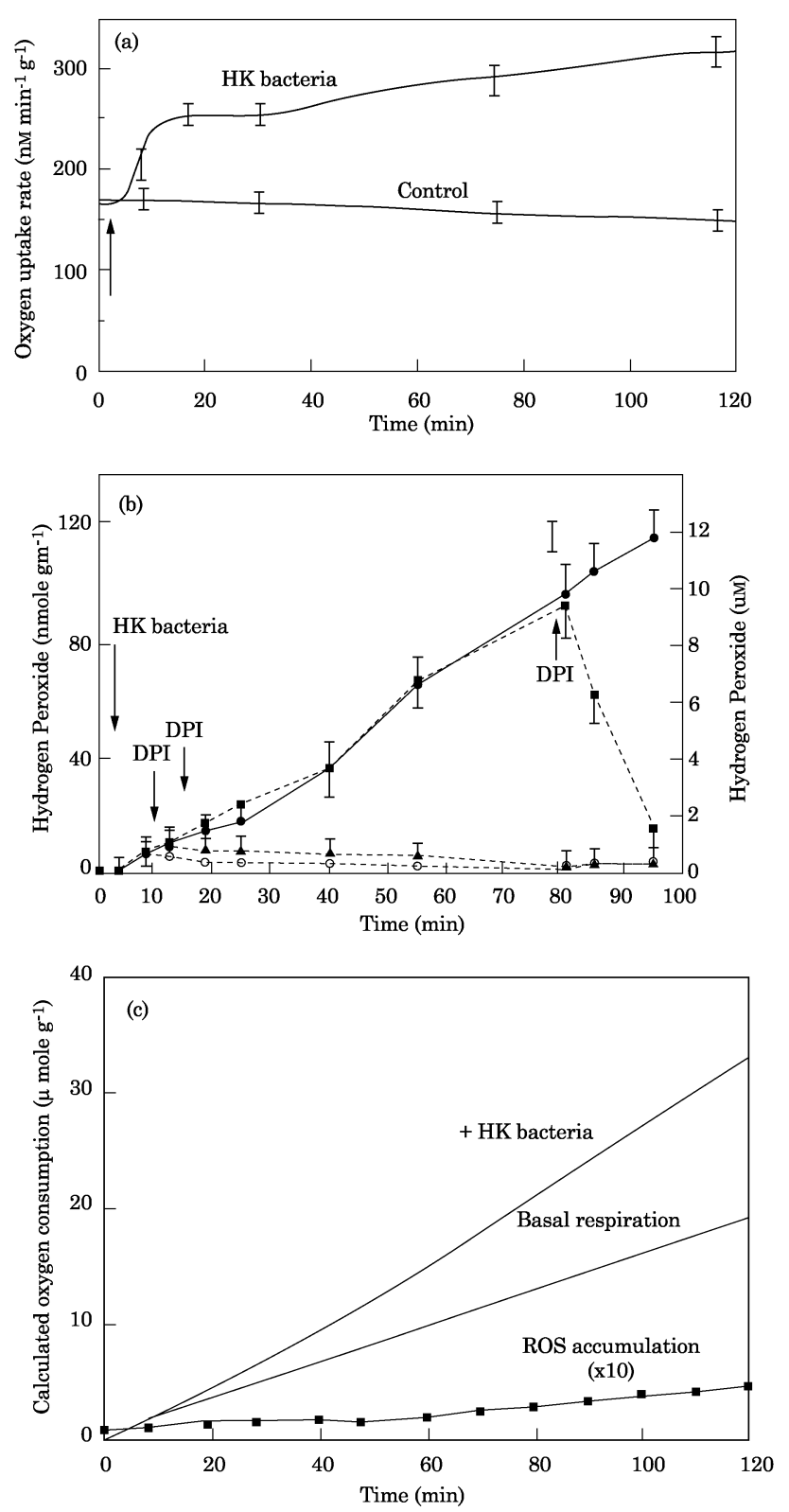

FIG. 1. Oxygen uptake response and ROS production in potato cell suspensions treated with HK-bacteria. HK-bacteria were added at the indicated time. (a) Oxygen uptake rates were monitored by oxygen electrodes. (b) Hydrogen peroxide accumulation was measured by the LDG assay. DPI $(10 \mu \mathrm{M})$ was added to cell suspensions at different times (arrows) after HK-bacteria: (O), no addition; (O), $10 \mathrm{~min}$; ( $) 15 \mathrm{~min}$; 80 min. (c) Total oxygen consumption calculated from the oxygen uptake rate. The estimated amount of oxygen consumed in ROS production is also shown. Errors bars represent one standard deviation.
Although the oxygen uptake response of tobacco suspension cells was concurrent with the elicited production of reactive oxygen species (ROS), very little of the elicited oxygen uptake was directly utilized in ROS production. Increased mitochondrial cytochrome oxidase activity appeared to be responsible for the majority of the oxygen uptake response.

The current study explores the oxygen uptake response in potato cells treated with HK-bacteria. Although potato suspension cells also responded to HK-bacteria with an immediate increase in oxygen uptake and concurrent ROS production, the results indicate that different mechanisms underlie the oxygen uptake responses of potato and tobacco cells. In both cell types, however, the amount of oxygen consumed greatly exceeded the amount required for ROS production. This report confirms increased oxygen uptake as an early recognition response in plants to pathogen-related stress.

\section{MATERIALS AND METHODS}

\section{Chemicals}

All chemicals were purchased from Sigma-Aldrich Chemicals, Inc. (St. Louis, MO, U.S.A.) with the exception of K-252, which was purchased from Fluka Chemical Corp. (Ronkonkoma, NY, U.S.A.). Diphenyleneiodonium chloride (DPI), K-252, and salicylhydroxamic acid (SHAM) were dissolved in DMSO and added to suspension cells for final concentrations of $10 \mu \mathrm{M}, 1.6 \mu \mathrm{M}$, and $1 \mathrm{~mm}$, respectively. Final concentration of DMSO added to cell suspensions did not exceed $0.01 \%$ and had no effect on oxygen uptake or luminol-dependent chemiluminescent (LDC) assays. Potassium cyanide (KCN) was prepared in $0.5 \mathrm{~mm}$ MES, $\mathrm{pH} 6.1$, and added to suspensions for a final concentration of $100 \mu \mathrm{M}$. Antimycin A was prepared in ethanol and added to suspension cells for a final concentration of $10 \mu \mathrm{M}$ and less than $0.05 \%$ ethanol. To determine the final concentration to use for each inhibitor, a concentration of $10^{-1}, 10$ and $10^{2}$ times more than the routinely reported concentration was tested (as shown with DPI, Fig. 2 insert). Except for DPI, the lowest concentration that gave more than $90 \%$ of the desired effect was used for the study.

\section{Plant cells}

Callus and suspension cells of potato (Solanum tuberosum cv. Kennebec) leaves were initiated and maintained as previously described [6]. Five day old potato cells were washed and resuspended in $20 \mathrm{ml}$ assay medium $(175 \mathrm{~mm}$ mannitol, $0.5 \mathrm{~mm} \mathrm{CaCl}_{2}, 0.5 \mathrm{mM} \mathrm{K}_{2} \mathrm{SO}_{4}$, and $0.5 \mathrm{~mm}$ MES, pH 6.1) for a final concentration of $0.1 \mathrm{~g} \mathrm{ml}^{-1}$ in $50 \mathrm{ml}$ beakers. Cells were equilibrated on a rotary shaker, 


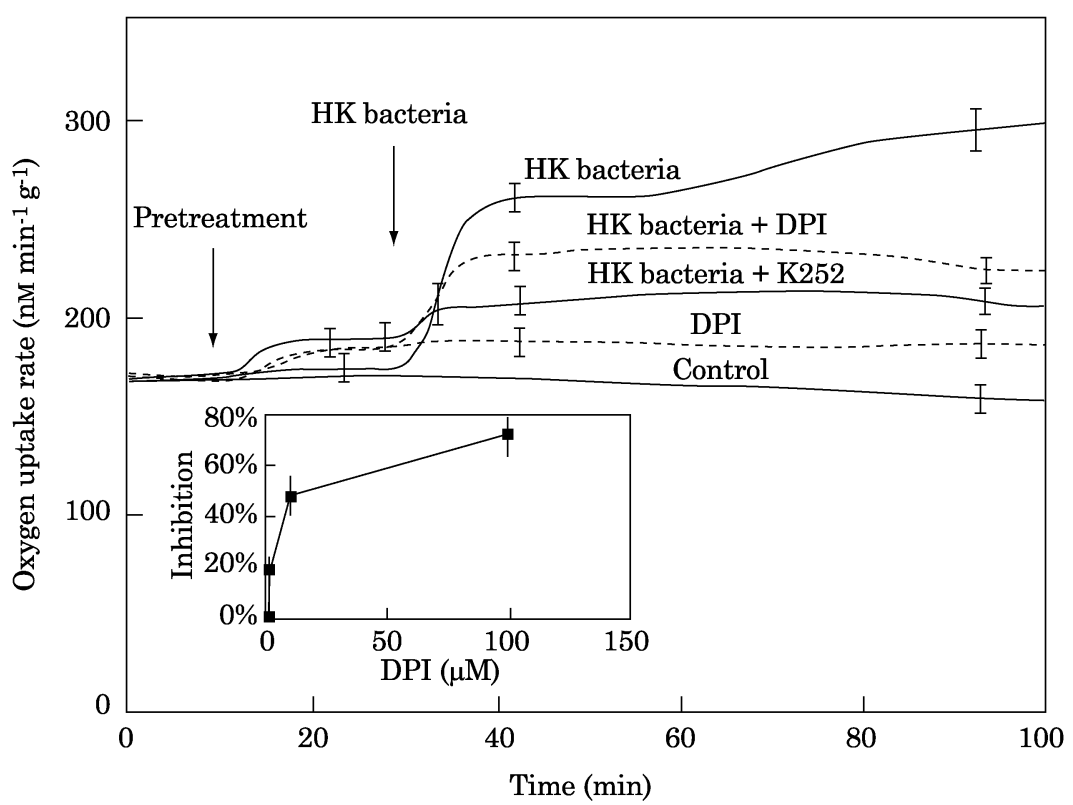

FIG. 2. Effect of DPI and K-252 on the oxygen uptake response of potato suspension cells treated with HK-bacteria. Suspensions were pretreated with either $10 \mu \mathrm{M}$ DPI or $1.6 \mu \mathrm{M} \mathrm{K}-252$ as described in the Materials and Methods section. Oxygen uptake was monitored by oxygen electrodes. Errors bars represent one standard deviation. Inset: Inhibition of the oxygen uptake response by different concentrations of DPI.

$200 \mathrm{rpm}$, at $27^{\circ} \mathrm{C}$. Separate but identical suspensions were prepared for oxygen uptake or ROS assays.

\section{HK-bacteria}

HK-bacteria were used as the elicitor to avoid complications of oxygen consumption by viable bacteria. Pseudomonas syringae pv. syringae $61 \mathrm{NalR}$, which causes the hypersensitive response on tobacco and potato plants, was routinely grown on King's B agar [18] augmented with naladixic acid $\left(50 \mu \mathrm{g} \mathrm{ml}^{-1}\right)$ and prepared for bioassays as previously described $[6,8]$. HK-bacteria were prepared by autoclaving bacterial suspensions for $15 \mathrm{~min}$. Addition of about $200 \mu \mathrm{l}$ to the $20 \mathrm{ml}$ of potato suspension cells resulted in a final concentration of HK-bacteria equiva-

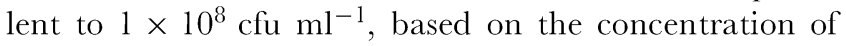
viable bacteria prior to autoclaving.

\section{Oxygen uptake measurement}

Oxygen uptake was measured using oxygen electrodes with computerized data acquisition as previously described [6]. This method allowed for simultaneous and continuous monitoring of oxygen concentration in up to 16 beakers of suspension cells. Cells were continuously shaken in beakers open to the atmosphere to assure adequate aeration. Changes in the steady state concentration of oxygen in beakers with cells was compared with beakers with no cells (100\% oxygen concentration at air saturation) to estimate the rate of oxygen uptake as previously described [6]. The basic concept underlying the technique is that changes in the rate of oxygen uptake result in a new steady state oxygen concentration in the buffer. Preliminary calibration under identical conditions and shaker speed but without cells allows calculation of the oxygen flux from the air, which, as described by Ficks Law, increases as oxygen concentration decreases in the buffer. Therefore at any oxygen concentration in the buffer, the rate of oxygen flux from air is known and should equal the oxygen uptake by the cells. Electrodes were routinely soaked in Tergazyme (Alconox, Inc., U.S.A.) for $10 \mathrm{~min}$ to eliminate any biological contaminants, and rinsed extensively with assay buffer prior to calibration in aerated assay buffer.

Suspension cells were treated with KCN, antimycin A, and/or SHAM to inhibit mitochondrial respiration prior to elicitation with HK-bacteria. As in the previous study $[8]$, we used the same criteria set forth in the literature $[20,25]$. Addition of HK-bacteria was postponed 10-15 min after pretreatment of cells with inhibitors to allow oxygen uptake rates to reach steady state conditions. All experiments were carried out at least three times with at least two replicates of each treatment per experiment.

\section{ROS measurement}

The LDC assay was used to measure $\mathrm{H}_{2} \mathrm{O}_{2}$ to estimate ROS accumulation [23]. Aliquots $(0 \cdot 4 \mathrm{ml})$ of suspension cells were dispensed into tubes, placed into the measuring 


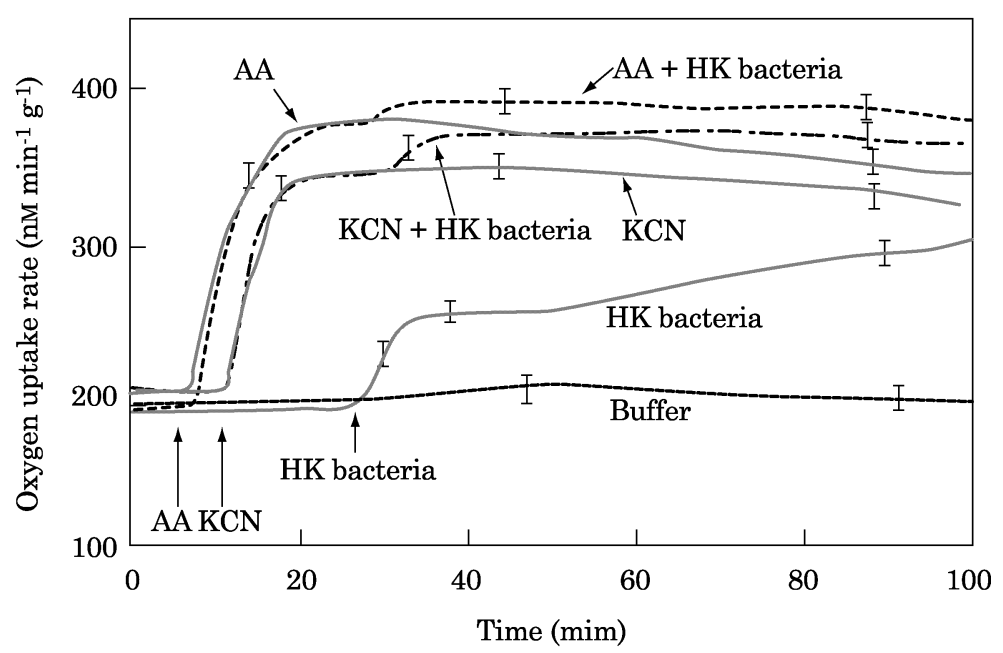

FIG. 3. Effect of cytochrome oxidase inhibitors, KCN and antimycin A on the oxygen uptake response of potato suspension cells treated with HK-bacteria. Suspension cells were treated with $100 \mu \mathrm{M} \mathrm{KCN}$ or $10 \mu \mathrm{M}$ antimycin A. Oxygen uptake rates were monitored by oxygen electrodes. Errors bars represent one standard deviation.

chamber of an EG\&G Berthold Autolumat 953 luminometer (Bad Wildbad, Germany), and automatically mixed with luminol and horseradish peroxidase for immediate measurement of luminescence. Standard curves were prepared with dilutions of $\mathrm{H}_{2} \mathrm{O}_{2}$ in assay buffer.

The scavenging rate of hydrogen peroxide by potato suspension cells was estimated by adding $20 \mu \mathrm{M} \mathrm{H}_{2} \mathrm{O}_{2}$ to a beaker containing $20 \mathrm{ml}$ of suspension cells prepared as described above. The concentration of $\mathrm{H}_{2} \mathrm{O}_{2}$ in the beakers over a $2 \mathrm{~h}$ period was estimated by LDG [5]. The scavenging rate constant for this concentration of potato cells was determined from this data with the aid of SAAM II software (SAAM Institute Inc., Seattle, WA, U.S.A.) as previously mentioned $[8]$.

\section{RESULTS}

Oxygen uptake response to HK-bacteria

Increased oxygen uptake by potato suspension cells in response to HK-bacteria appeared to occur in two stages. The first stage started 3-4 min after addition of HKbacteria [Fig. 1(a)]. Over a $5-7 \mathrm{~min}$ period, the rate of oxygen uptake increased to a new steady state, approximately $80 \mathrm{nM} \mathrm{m^{-1 }} \mathrm{g}^{-1}$ greater than the basal rate of about $170 \mathrm{~nm} \mathrm{~min}{ }^{-1} \mathrm{~g}^{-1}$. The second stage occurred $20-$ 30 min after the new steady state was established. During this stage the oxygen uptake rate of the HK-bacteria treated cells steadily increased an additional $50-70 \mathrm{~nm}$ $\min ^{-1} \mathrm{~g}^{-1}$ over a $90 \mathrm{~min}$ period of monitoring. Continuous shaking of the cell cultures assured that the media was consistently aerated throughout the experiment and oxygen concentrations were not limiting.
Concomitant with the oxygen uptake response, potato cells treated with HK-bacteria produced increasing levels of ROS [Fig. 1(b)]. Elevated $\mathrm{H}_{2} \mathrm{O}_{2}$ levels could be detected $10 \mathrm{~min}$ after treatment with HK-bacteria. Concentrations increased to about $12 \mu \mathrm{M} \quad \mathrm{H}_{2} \mathrm{O}_{2}$, or about $120 \mathrm{nM} \mathrm{g}^{-1}$ cells, over the first $100 \mathrm{~min}$.

\section{Effect of DPI and $K-252$ on the oxygen metabolism}

The ROS response of potato suspension cells to HK-bacteria was completely inhibited by pretreatment with $10 \mu \mathrm{M}$ DPI [12], an inhibitor of NAD $(\mathrm{P}) \mathrm{H}$ oxidases [Fig. 1(b)] or with $1.6 \mu \mathrm{M} \mathrm{K}-252$ [17], a protein kinase inhibitor (data not shown). Both compounds have been reported to inhibit ROS production in plant cells [2, 9, $21]$.

Addition of $10 \mu \mathrm{M}$ DPI to potato cells 8 or 80 min after addition of HK-bacteria resulted in an immediate decrease of $\mathrm{H}_{2} \mathrm{O}_{2}$. Although DPI has been shown to be an inhibitor of $\mathrm{NAD}(\mathrm{P}) \mathrm{H}$ oxidases in plant and animal cells $[2,12,21]$, it also has been shown to accelerate $\mathrm{H}_{2} \mathrm{O}_{2}$ scavenging by peroxidase in the presence of reductants such as $\mathrm{NAD}(\mathrm{P}) \mathrm{H}[4,14]$. Therefore inhibition of ROS by DPI does not necessarily prove the involvement of $\mathrm{NAD}(\mathrm{P}) \mathrm{H}$ oxidases.

The scavenging of $\mathrm{H}_{2} \mathrm{O}_{2}$ by potato suspensions was estimated by adding $20 \mu \mathrm{M} \mathrm{H} \mathrm{H}_{2} \mathrm{O}_{2}$ into identical beakers and following the decrease in concentration [5]. The rate constant was estimated to be $0.075 \mathrm{~min}^{-1}$, using SAAM II software as described in Materials and Methods. Using this scavenging rate and based on the assumption that a net of one molecule of oxygen was required for the production of one molecule of $\mathrm{H}_{2} \mathrm{O}_{2}$, the oxygen consumption required for $\mathrm{H}_{2} \mathrm{O}_{2}$ production was calculated 


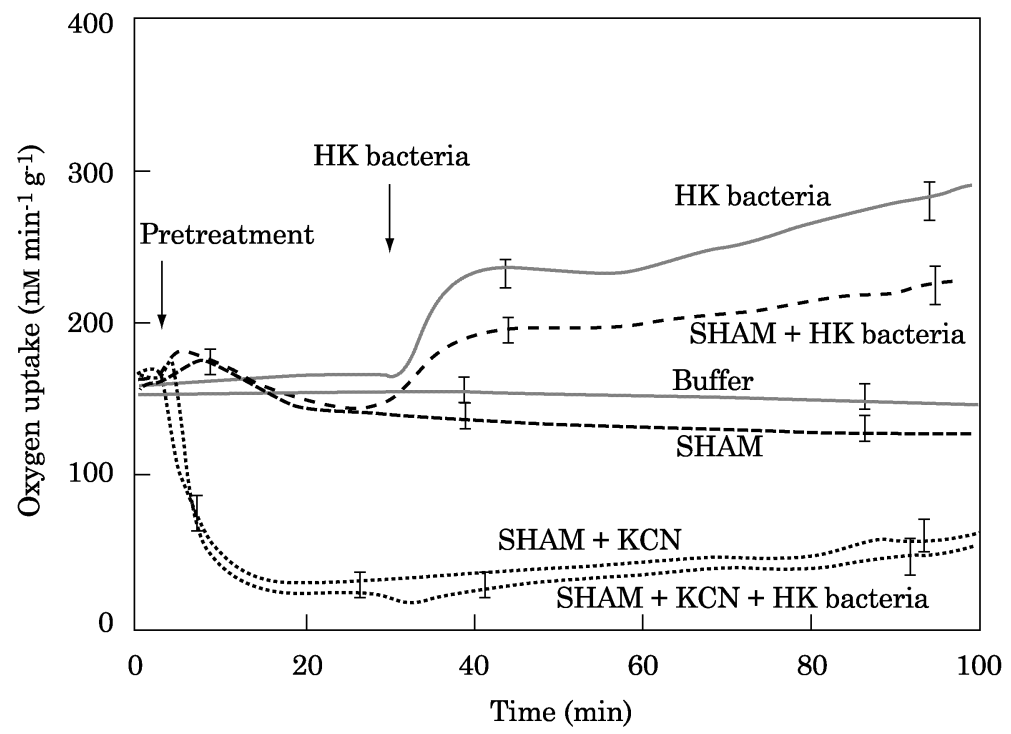

FIG. 4. Effect of alternate oxidase inhibitor, SHAM, and KCN on the oxygen uptake response of potato suspension cells treated with HK-bacteria. Suspension cells were pretreated with $1 \mathrm{~mm} \mathrm{SHAM}$ alone or with $100 \mu \mathrm{M} \mathrm{KGN}$. HK-bacteria were added at the indicated time. Oxygen uptake rates were monitored by oxygen electrodes. Errors bars represent one standard deviation.

[Fig. 1(c)]. When compared to the total oxygen consumption, calculated from the uptake rates, by the potato cells after treatment with HK-bacteria it was apparent that only a minor fraction of the increased oxygen uptake was involved in ROS production [Fig. 1(c)].

Treatment of cells with $10 \mu \mathrm{M}$ DPI induced a slight increase, $15 \mathrm{~nm} \mathrm{~min}{ }^{-1} \mathrm{~g}^{-1}$, in oxygen uptake rates of potato cells (Fig. 2). Upon treatment of these cells with HK-bacteria the oxygen uptake response was inhibited nearly $50 \%$ compared to control cells. Higher concentrations of DPI inhibited the oxygen uptake response further, $70 \%$ inhibition with $100 \mu \mathrm{M}$ DPI (Fig. 2, inset). However, DPI was not as effective an inhibitor of the oxygen uptake response in potato compared with tobacco $[8]$ where concentrations of $1-100 \mu \mathrm{M}$ DPI inhibited the oxygen uptake rate by $80-90 \%$.

K-252 strongly inhibited the oxygen uptake response (Fig. 2). Addition of 1.6 $\mu \mathrm{M} \mathrm{K-252} \mathrm{inhibited} \mathrm{the} \mathrm{response}$ by $80-90 \%$ indicating that protein phosphorylation may be involved in triggering the response. Control cells treated with $\mathrm{K}-252$ alone reacted with a $18 \mathrm{nM} \mathrm{min}{ }^{-1} \mathrm{~g}^{-1}$ increase in oxygen uptake, similar to the DPI-treated controls. Interestingly, cells treated with either DPI or K252 did not undergo the second stage of the oxygen uptake response observed in potato cells treated with HKbacteria.

\section{Effect of respiratory inhibitors on oxygen uptake rates}

To examine the contribution of respiration to the elicited oxygen uptake response, potato cells were treated with KGN or antimycin A, inhibitors of the mitochondrial cytochrome oxidase (Fig. 3). Untreated potato cells responded to $100 \mu \mathrm{M} \mathrm{KCN}$ or $10 \mu \mathrm{M}$ antimycin $\mathrm{A}$ by nearly doubling the oxygen uptake rate. This is likely due to a shift of electrons to the alternate, cyanide-resistant oxidase pathway $[3,25]$ where ATP production is less efficient and, therefore, requires increased electron transport and oxygen uptake. Addition of HK-bacteria to $\mathrm{KCN}$ - or antimycin A-pretreated cells resulted in an oxygen uptake response that was inhibited by 70 or $90 \%$ inhibition, respectively.

Because of the large increase in basal oxygen uptake of the potato cells caused by these respiratory inhibitors, it is difficult to establish definitively if the inhibited oxygen uptake response is solely due to inhibition of the cytochrome oxidases. The greatly increased consumption of oxygen caused by pretreatment with the $\mathrm{KCN}$ and antimycin A, could compete for oxygen and thereby indirectly partially inhibit the oxygen uptake response. However, assuming these inhibitors worked as expected, these results indicate that the mitochondrial cytochrome oxidase activity increases upon recognition of the HKbacteria and is at least partially responsible for the oxygen uptake response. Here again, the second stage involving the slow continuous increase of oxygen uptake rate did not occur in the presence of the cytochrome oxidase inhibitors.

Potato suspensions treated with $1.0 \mathrm{~mm}$ SHAM, an inhibitor of the alternate oxidase, responded with a transient increase in respiration, returning to sub-basal rates within about $30 \mathrm{~min}$ (Fig. 4). Pretreatment with SHAM inhibited the oxygen uptake response to HKbacteria about $25 \%$ relative to the SHAM control. When potato suspensions were treated simultaneously with both $1 \mathrm{~mm}$ SHAM and $100 \mu \mathrm{M}$ KGN oxygen uptake rates 


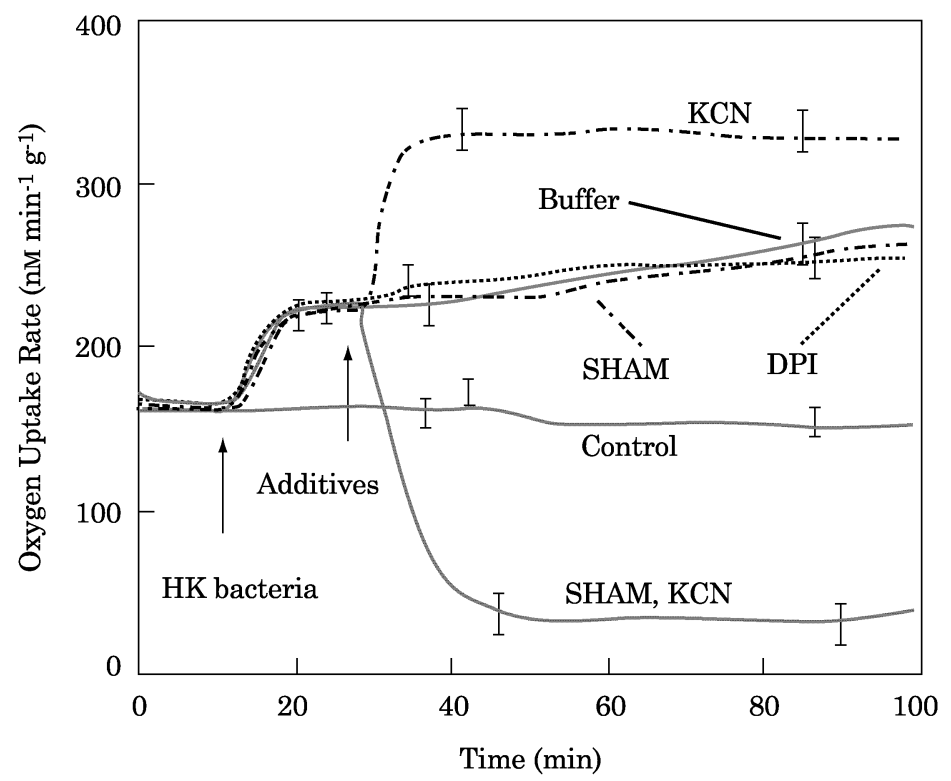

FIG. 5. Effect of DPI and respiratory inhibitors on the oxygen uptake response of potato suspension cells after elicitation with HKbacteria. Suspension cells were treated with HK-bacteria followed 18 min later with DPI, KCN, SHAM, or KCN and SHAM together. Oxygen uptake rates were monitored by oxygen electrodes. Errors bars represent one standard deviation.

immediately decreased, indicating inhibition of basal mitochondrial respiration (Fig. 4). Pretreatment of cells with SHAM and KCN appeared to completely inhibit the oxygen uptake response to HK-bacteria. Unlike the other inhibitor pretreatments, cells pretreated with SHAM displayed the second stage in which the oxygen uptake rate continuously increased at a slow rate.

To further explore the involvement of respiration and ROS production in the oxygen uptake response, cells were first elicited with HK-bacteria and then inhibitors were added 18 min later, after the initial rapid increase of oxygen uptake (Fig. 5). KCN caused a large increase in oxygen uptake as it did when added prior to HK-bacteria (Fig. 3). Addition of SHAM or DPI had little effect except that DPI appeared to reduce the second stage increase. However, addition of SHAM and KCN together reduced the oxygen uptake rate well below the controls. These results support the conclusion that mitochondrial respiration is likely to be responsible for the majority of the oxygen uptake response (Fig. 5).

\section{DISCUSSION}

As in a previous study with tobacco suspension cells [8], potato cells responded to HK-bacteria with an immediate increase in oxygen uptake and a concomitant increase in ROS production (Fig. 1). In both of these cell systems, increased mitochondrial respiration appears to be primarily responsible for the majority of the oxygen uptake, with less than $5 \%$ utilized in ROS production
[Fig. 1(c)]. Despite these similarities, however, the elicited oxygen uptake response of potato cells appears to have several noteworthy differences from the tobacco response.

In the previous study, tobacco suspension cells responded to HK-bacteria with an immediate increase in oxygen uptake that peaked at approximately $20 \mathrm{~min}$ after elicitation and then sharply declined to a steady state that was about twice the original basal rate. In the current study, potato cells also responded to the addition of HK-bacteria with an immediate and rapid increase in oxygen uptake, reaching a new steady state within 5-7 min. Unlike tobacco, however, potato cells displayed a second stage of the response: a small but continuous increase in the oxygen uptake rate at approximately 20-30 min after elicitation [Fig. 1(a)].

ROS accumulation in the potato cell suspension increased steadily throughout the monitoring period [Fig. 1(b)]. This differs from the kinetics of ROS production previously demonstrated in a variety of elicited cell suspensions such as bean, soybean, tobacco, and rose cells $[1,7,10,11,13,19,22,24]$. Generally there is a rapid but transient production of ROS in response to elicitor treatment. The prolonged ROS production by potato cells treated with $\mathrm{HK}$-bacteria is not characteristic of an $\mathrm{NAD}(\mathrm{P}) \mathrm{H}$ oxidase or synthase that, through signaling cascades, are rapidly activated and then down-regulated. However, peroxidases, which have been hypothesized to produce ROS, have the potential for prolonged production of ROS provided sufficient reductant, such as $\mathrm{NAD}(\mathrm{P}) \mathrm{H}$, is available $[4,10,11]$. 
Another likely source of the increased ROS would be the mitochondria where spurious electrons from the activated transport chain pass directly to oxygen prior to the terminal oxidase $[15,16]$. It has been reported that in times of stress as much as $1-10 \%$ of the electron transport in mitochondria results in ROS. This would be an example of an aberrant electron flux that results in a short circuit of the oxidative cycle and the energy of the electron does not get transferred to ATP but results in often unwanted reactions unless the ROS is scavenged by antioxidant mechanisms.

Pretreatment of cells with various respiratory inhibitors pointed out further differences between the oxygen uptake and ROS responses of potato and tobacco cells. Addition of the cytochrome inhibitors, KCN or antimycin A, to the potato cell suspensions increased the basal oxygen uptake rate by as much as $60-100 \%$ (Fig. 3), while in the previous study with tobacco the basal rate increased by less than $10 \%$. The traditional explanation for the increase is that there is a shift in the electron transport chain to the less efficient alternate oxidase. Since less ATP is produced per oxygen molecule reduced, higher rates of electron transport are needed to maintain the cell's current level of metabolic activity. The greater increase in oxygen uptake of potato compared to tobacco caused by these inhibitors indicates that the potato cells may have a relatively greater demand for ATP due to a higher metabolic activity. This would be consistent with its higher basal oxygen uptake rate of $180 \mathrm{nM} \mathrm{min}^{-1} \mathrm{~g}^{-1}$ compared to $100 \mathrm{nM} \mathrm{min}{ }^{-1} \mathrm{~g}^{-1}$ of tobacco.

An interesting but unusual aspect of the oxygen uptake response as well as the ROS response in the potato cells is the second stage involving the continued increase in the uptake rate over several hours. This stage of the response was inhibited by DPI, K-252, and KCN but not SHAM. This was found not to be due to bacterial contamination and multiplication. Until these techniques are successfully applied to tissue, it will not be known if this phenomenon is an artifact of the suspension cells.

The addition of SHAM, the alternate oxidase inhibitor, before or after the HK-bacteria significantly inhibits the oxygen uptake response in potato but has little effect in tobacco. This again suggests a different and greater role for the alternate oxidase in the oxygen uptake response in the potato cells than in tobacco cells.

In summary, the potato cells responded to heat-killed bacteria with an increased oxygen uptake similar to the tobacco cells. However, the response had several different characteristics: (1) no transient peak during stage 1; (2) a prolonged increase in the oxygen uptake rate during stage 2; (3) inhibition by SHAM was greater than DPI, suggesting the alternate oxidase and perhaps peroxidases may be more involved in the response than the $\mathrm{NAD}(\mathrm{P}) \mathrm{H}$ oxidase.

(C) 2001 US Government

\section{REFERENCES}

1. Apostol I, Heinstein PF, Low PS. 1989. Rapid stimulation of an oxidative burst during elicitation of cultured plant cells. Plant Physiology 90: 109-116.

2. Auh G-K, Murphy TM. 1995. Plasma membrane redox enzyme is involved in the synthesis of $\mathrm{O}_{2}^{-}$and $\mathrm{H}_{2} \mathrm{O}_{2}$ by Phytophthora elicitor-stimulated rose cells. Plant Physiology 107: 1241-1247.

3. Bahr JT, Bonner WD. 1973. Cyanide-insensitive respiration. The steady states of skunk cabbage spadix and bean hypocotyl mitochondria. Journal of Biological Chemistry 248: 3441-3445.

4. Baker GJ, Deahl K, Domek J, Orlandi JW. 1998. Oxygen metabolism in plant/bacteria interactions: effect of DPI on the pseudo-NAD $(\mathrm{P}) \mathrm{H}$ oxidase activity of peroxidase. Biochemical and Biophysical Research Communications 252: 461-464.

5. Baker CJ, Harmon GL, Glazener JA, Orlandi EW. 1995. A non-invasive technique for monitoring peroxidative and $\mathrm{H}_{2} \mathrm{O}_{2}$-scavenging activities during interactions between bacterial plant pathogens and suspension cells. Plant Physiology 108: 353-359.

6. Baker CJ, Mock NM, Deahl K, Domek J. 1997. Monitoring the rate of oxygen consumption in plant cell suspensions. Plant Cell, Tissue and Organ Culture 51: 111-117.

7. Baker CJ, Orlandi EW. 1999. Active oxygen and pathogenesis in plants. In: Stacey G, Keen NT, eds. Plant-Microbe Interactions, Vol. 4. St. Paul, MN: APS Press, 81-119.

8. Baker CJ, Orlandi EW, Deahl K. 2000. Oxygen metabolism in plant/bacteria interactions: characterization of the oxygen uptake response of plant suspension cells. Physiological and Molecular Plant Pathology 57: 159-167.

9. Baker CJ, Orlandi EW, Mock NM. 1993. Harpin, an elicitor of the hypersensitive response in tobacco caused by Erwinia amylovora, elicits active oxygen production in suspension cells. Plant Physiology 102: 1341-1344.

10. Bolwell GP, Butt VS, Davies DR, Zimmerlin A. 1995. The origin of the oxidative burst in plants. Free Radical Research 23: 517-532.

11. Bolwell GP, Davies DR, Gemish C, Auh GK, Murphy TM. 1998. Comparative biochemistry of the oxidative burst produced by rose and French bean cell reveals two distinct mechanisms. Plant Physiology 116: 1379-1385.

12. Cross AR, Jones OTG. 1986. The effect of the inhibitor diphenylene iodonium on the superoxide-generating system of neutrophils. Biochemistry Fournal 237: 111-116.

13. Doke N. 1985. NADPH-dependent $\mathrm{O}_{2}^{-}$generation in membrane fractions isolated from wounded potato tubers inoculated with Phytophthora infestans. Physiological Plant Pathology 27: 311-322.

14. Frahry G, Schopfer P. 1998. Inhibition of the $\mathrm{O}_{2}$-reducing activity of horseradish peroxidase by diphenylene iodonium. Phytochemistry 48: 223-227.

15. Gomez-Diaz G, Barroso MP, Navas P. 2000. Plasma membrane co-enzyme $\mathbf{Q}(10)$ and cell growth. Protoplasma 214: 19-23.

16. Gutteridge JMC, Halliwell B. 1999. Antioxidant protection and oxygen radical signaling. In: Gilbert DL, Colton CA, eds. Reactive Oxygen Species in Biological Systems: An Interdisciplinary Approach. New York, NY: Kluwer Academic/Plenum Publishers, 189-218.

17. Kase H, Iwahashi K, Nakanishi S, Matsuda Y, Yamada K, Takahashi M, Murakata G, Sato A, Kaneko M. 
1987. K-252 compounds, novel and potent inhibitors of protein kinase $\mathrm{C}$ and cyclic nucleotide-dependent protein kinases 142: 436-440.

18. King EO, Ward MK, Raney DE. 1954. Two simple media for the demonstration of phycocyanin and fluorescin. Journal of Laboratory and Clinical Medicine 44: 301-307.

19. Lamb G, Dixon RA. 1997. The oxidative burst in plant disease resistance. Annual Review of Plant Physiology and Plant Molecular Biology 48: 251-275.

20. Laties GG. 1982. The cyanide-resistant, alternative path in higher plant respiration. Annual Review of Plant Physiology 33: $519-555$.

21. Levine A, Tenhaken R, Dixon R, Lamb G. 1994. $\mathrm{H}_{2} \mathrm{O}_{2}$ from the oxidative burst orchestrates the plant hypersensitive disease resistance response. Cell $\mathbf{7 9}$ : 583-593.
22. Low PS, Dwyer SC. 1994. Comparison of the oxidative burst signaling pathways of plants and human neutrophils. Proceedings of 1994 Korean Botanical Society. Seoul, Korea: Ewha Womans University, 75-87.

23. Orlandi EW, Hutcheson SW, Baker CJ. 1992. Early physiological responses associated with race-specific recognition in soybean leaf tissue and cell suspensions treated with Pseudomonas syringae pv. glycinea. Physiological and Molecular Plant Pathology 40: 173-180.

24. Robertson D, Davies DR, Gemish G, Jupe SC, Bolwell GP. 1995. Rapid changes in oxidative metabolism as a consequence of elicitor treatment of suspension-cultured cells of French bean (Phaseolus vulgaris L.). Plant Molecular Biology 27: 59-67.

25. Vanlerberghe GC, McIntosh L. 1997. Alternative oxidase: from gene to function. Annual Review of Plant Physiology and Plant Molecular Biology 48: 703-734. 